\title{
THE EFFECT OF PARTICLE SIZE ON THE LEACHING OF Scirpus cubensis POEPP \& KUNTH
}

\author{
BIANCHINI Jr., I. ${ }^{1,2}$ and ANTONIO, R. M. ${ }^{2}$ \\ ${ }^{1}$ Departamento de Hidrobiologia, Universidade Federal de São Carlos, Via Washington Luís, km 235, \\ CEP 13565-905, C.P. 676, São Carlos, SP, Brazil \\ ${ }^{2}$ Programa de Pós-graduação em Ecologia e Recursos Naturais, Universidade Federal de São Carlos, \\ Via Washington Luís, km 235, CEP 13565-905, C.P. 676, São Carlos, SP, Brazil \\ Correspondence to: Irineu Bianchini Jr., Departamento de Hidrobiologia, Universidade Federal de São Carlos, \\ Via Washington Luís, km 235, CEP 13565-905, C.P. 676, São Carlos, SP, Brazil, e-mail: irineu@ power.ufscar.br \\ Received March 5, 2002 - Accepted August 27, 2002 - Distributed May 31, 2003
}

(With 5 figures)

\begin{abstract}
An investigation was made on the effects of detritus particle size on leaching rates in organic matter, and the associated environmental changes caused by detritus re-cycling in an oxbow lake (Lagoa do Infernão). Experiments were conducted during the decay of an aquatic macrophyte specie, $S$. cubensis, which in turn led to the formation of colored compounds. The S. cubensis were collected from the Lagoa do Infernão and taken to the laboratory where they were washed, dried, and fractionated using a sieve pedological set. The detritus was classified into six groups according to size, viz. 100, $10,1.13,0.78,0.61$, and $0.25 \mathrm{~mm}$. Overall, the fragmentation process tended to increase the detritus fraction to be dissolved and to decrease the leaching rates owing to the possible dissolution of refracting matter. Fragmentation also caused the amount of colored compounds to increase and appeared to favor dissolved electrolyte release. Finally, in Lagoa do Infernão fragmentation is probably mediated by the metabolic action of benthic communities.
\end{abstract}

Key words: leaching, detritus, coloured compounds, kinetic, aquatic macrophyte.

\section{RESUMO}

\section{O efeito do tamanho de partícula na lixiviação de Scirpus cubensis Poepp \& Kunth}

Foram realizados estudos a fim de verificar os efeitos do tamanho de partícula dos fragmentos nos coeficientes de lixiviação da matéria orgânica e as mudanças, associadas ao ambiente, causadas pela ciclagem de detritos em uma lagoa marginal (lagoa do Infernão). Os experimentos foram desenvolvidos durante a decomposição de uma espécie de macrófita aquática, Scirpus cubensis, que também gerou compostos coloridos. Os exemplares de $S$. cubensis foram coletados na lagoa do Infernão e levados ao laboratório, onde foram lavados, secos e fracionados em um conjunto de peneiras pedológicas. Os detritos foram classificados em seis grupos, de acordo com o tamanho: 100, 10, 1,13, 0,78, 0,61 e $0,25 \mathrm{~mm}$. No geral, o processo de fragmentação tendeu a incrementar a fração do detrito a ser dissolvida e diminuir os coeficientes de lixiviação, em razão de possível dissolução da matéria orgânica refratária. A fragmentação também favoreceu a formação de compostos coloridos e a liberação de eletrólitos dissolvidos. Na lagoa do Infernão, a fragmentação, provavelmente, é mediada pela ação metabólica da comunidade bentônica.

Palavras-chave: lixiviado, detrito, compostos coloridos, cinética, macrófita aquática. 


\section{INTRODUCTION}

It is now well established that an efficient method for describing aquatic ecosystems consists in conducting field and/or laboratory experiments together with mathematical simulation studies. This is particularly true when experimental results provide essential information for the parameters employed in fitting the data to a given theoretical model. This philosophy is being adopted in an ongoing project aimed at modeling the detritus recycling processes in an oxbow lake. In the present work we shall be concerned with the experimental activities within this project, focusing on the contribution from aquatic macrophytes to organic matter detritus in an oxbow lake. It is expected that such a contribution could significantly alter the physical, chemical, and biological characteristics of the water and sediments. It can also affect the functioning of other processes in the ecosystem such as primary and secondary productions. For an oxbow lake the hydrological regime is constituted of periodical pulses and may be an important factor in a number of processes in the ecosystem, including the detritus dynamics of vegetal communities (Albuquerque, 1992; Ballester, 1994; Howard-Williams et al., 1989; Nogueira, 1989; Santos \& Mozeto, 1992). For example, in Amazonian "várzea" lakes approximately 90 percent of the vegetation may die when the water level drops during the dry season (Junk, 1980).

Degradation of detritus may alter the ecosystems by several means: 1) release of organic compounds and nutrients; 2) formation and accumulation of dissolved humic compounds; 3 ) increase in dissolved oxygen demand; and 4) accumulation of particulate detritus in the sediments. The simplest way to monitor changes in organic resources due to degradation is by measuring their mass loss (Swift et al., 1979). Detailed analyses show that in addition to mass loss, changes also occur in the chemical composition of the remaining matter. These alterations are caused by three distinct processes: leaching, catabolism, and fragmentation (Swift et al., 1979).

Leaching is the abiotic process whereby soluble matter is removed from a resource through the action of water. It therefore causes both weight loss and changes in the original chemical composition of the detritus. In the ecosystem, leaching may promote transference of soluble compounds from one place to another, where they may suffer further decomposition (Swift et al., 1979). Catabolism is a biochemical process in which complex organic compounds are transformed into smaller and simpler organic and inorganic molecules. Over a limited given period catabolism may be incomplete, thus generating intermediate or re-synthesized compounds such as humic ones (Bianchini Jr. et al., 1984; Stevenson, 1982; Thurman, 1985; Toledo, 1973; Wetzel, 1983). In the fragmentation process, detritus particle size is reduced. Fragmentation differs from catabolism because of its physical nature, even though in some cases it may be associated with decomposer feeding activity. In this case, during digestion fragmentation may be accompanied by catabolic changes. The remaining matter is eliminated in the form of small particles whose chemical composition differs from that of the ingested food material (Swift et al., 1979). Detritus fragmentation may also occur due to climatic changes and the turbulent action of water and wind (Lush \& Hynes, 1973).

In practice, these three processes act simultaneously on a given organic resource and may be very difficult to distinguish. The essays carried out here were specifically designed for investigating fragmentation effects on the decay processes of an aquatic plant species (Scirpus cubensis) dominant in an oxbow lake in the Mogi-Guaçu River (São Paulo State, Brazil). The study comprises the following steps: 1) accompanying the destination of some detritus fractions by analyzing the remaining material; 2) describing a kinetics model that accounts for the detrital biomass flow during the leaching process; 3 ) describing the leaching rates as a function of the initial size of the detritus particles; and 4) discussing possible effects of the leaching process on the recycling dynamics of detrital organic matter in the Lagoa do Infernão.

\section{MATERIALS AND METHODS}

\section{Experimental procedures}

Samples of Scirpus cubensis Poepp \& Kunth were collected from an oxbow lake named Lagoa do Infernão (21 $35^{\prime}$ 'S and $\left.47^{\circ} 51^{\prime} \mathrm{W}\right)$, located in the Jataí Ecological Station (São Paulo State, Brazil). The lake is located in the laboratory, the aquatic macrophytes were selected, washed with tap water, and dried at 
$60^{\circ} \mathrm{C}$ to a constant weight. They were then ground and the fragments further fractionated using a pedological sieve set. This procedure resulted in 6 groups of particle sizes, as shown in Table 1. For each group, 10 bottles were filled with $80 \mathrm{ml}$ distilled water and $2 \mathrm{~g}$ aquatic macrophyte fragments. The bottles were shaken at given periods. The particulate organic matter (POM) was separated from the dissolved matter (DOM), using filter paper, at the following times: $0,0.5,1.4,2.5,3.4,4.7,5.7,7.7,8.6,9.9$, and 11.4 days. The POM and DOM amounts were measured using the gravimetric method, for which the particulate detritus and the leachate were dehydrated at $60^{\circ} \mathrm{C}$. The use of distilled water rather than water from Lagoa do Infernão was to avoid conditions favorable to leachate consumption. Using distilled water and under anaerobic conditions, aeration and microorganism occurrences were minimized. Consequently, the DOM mineralization rates were low which made it easier to apply the kinetics model of Levenspiel (1986), as discussed in the next section.

Prior to DOM quantification, its $\mathrm{pH}$, electrical conductivity, and optical density were measured. The $\mathrm{pH}$ was obtained using the potentiometric method, and optical density was measured with a photocolorimeter (at $430 \mathrm{~nm}$ ). Before the optical density measurement, the filtrate volume was completed to $100 \mathrm{ml}$.

\section{Theoretical model}

Considering that organic resources decay processes follow a first-order kinetics (Brezonik,
1994; Jorgensen, 1986; Mindermann, 1968), the decomposition may be simplisticly described according to the following equations:

1) POM decay (leaching and mineralization processes)

$$
\frac{\mathrm{dC}_{\mathrm{POM} 1}}{\mathrm{dt}}=-\mathrm{k}_{1} \mathrm{C}_{\mathrm{POM} 1}-\mathrm{k}_{3} \mathrm{C}_{\mathrm{POM} 2}
$$

where:

$\mathrm{C}_{\text {POM1 }}=$ change per unit of time in the amount of POM fractions associated with protoplasmic portions and other soluble compounds;

$\mathrm{C}_{\mathrm{POM} 2}=$ change per unit of time in the amount of POM refracted portions (e.g., cellulose, lignin);

$\mathrm{k}_{1}=$ Leaching constant rate $\left(\right.$ day $\left.^{-1}\right)$;

$\mathrm{k}_{3}=$ oxidation (mineralization) constant rate $\left(\right.$ day $\left.^{-1}\right)$.

2) Formation of DOM and mineralization

$$
\frac{\mathrm{dC}_{\mathrm{DOM}}}{\mathrm{dt}}=\mathrm{k}_{1} \mathrm{C}_{\mathrm{POM} 1}-\mathrm{k}_{2} \mathrm{C}_{\mathrm{DOM}}
$$

where:

$\mathrm{C}_{\mathrm{DOM}}=$ change per unit of time in DOM concentration;

$\mathrm{k}_{2}=$ mineralization constant rate (formation of inorganic substances, $\mathrm{CO}_{2}$, and other gases), day ${ }^{-1}$.

TABLE 1

Particle sizes selected.

\begin{tabular}{|c|c|c|}
\hline Group & Size range $(\mathbf{m m})$ & Size average $(\mathbf{m m})$ \\
\hline I & 100 & 100 \\
\hline II & 10 & 10 \\
\hline III & $0.84<x<1.41$ & 1.13 \\
\hline IV & $0.71<x<0.84$ & 0.78 \\
\hline V & $0.50<x<0.71$ & 0.61 \\
\hline VI & $\mathrm{x}<0.50$ & 0.25 \\
\hline
\end{tabular}


3) Formation of gases and inorganic substances (mineralization of POM refracting fractions)

$$
\frac{\mathrm{dC}_{\mathrm{CO} 2}}{\mathrm{dt}}=\mathrm{k}_{3} \mathrm{C}_{\mathrm{POM} 2}
$$

where:

$\mathrm{C}_{\mathrm{CO} 2}=$ amount per unit of time of inorganic substances, $\mathrm{CO}_{2}$, and other gases.

\section{RESULTS AND DISCUSSION}

Time dependence of POM and DOM amounts is illustrated in Table 2. It may be concluded that the gravimetric method was not sufficiently sensitive for investigating the small changes in the biomass of the particulate detritus (POM).

This methodological incapacity is probably associated with the adherence of microorganisms during the decay and filtration processes.

TABLE 2

Time evolution of POM and DOM amounts during the decay of Scirpus cubensis fragments.

\begin{tabular}{|c|c|c|c|c|c|c|}
\hline $\begin{array}{l}\text { Time } \\
\text { (day) }\end{array}$ & $\begin{array}{c}\text { Pom } \\
(\%)\end{array}$ & $\begin{array}{l}\text { Dom } \\
(\%)\end{array}$ & $\begin{array}{c}\text { Pom } \\
(\%)\end{array}$ & $\begin{array}{c}\text { Dom } \\
(\%)\end{array}$ & $\begin{array}{l}\text { Pom } \\
(\%)\end{array}$ & $\begin{array}{c}\text { Dom } \\
(\%)\end{array}$ \\
\hline & \multicolumn{2}{|c|}{ Group I } & \multicolumn{2}{|c|}{ Group II } & \multicolumn{2}{|c|}{ Group III } \\
\hline 0.00 & 100.00 & 0.00 & 100.00 & 0.00 & 100.00 & 0.00 \\
\hline 0.50 & 93.62 & 4.65 & 90.52 & 9.35 & 91.93 & 5.65 \\
\hline 1.40 & 93.46 & 5.15 & 91.35 & 7.75 & 93.55 & 5.40 \\
\hline 2.45 & 96.36 & 4.50 & 91.77 & 7.55 & 94.27 & 6.40 \\
\hline 3.35 & 94.91 & 2.70 & 92.80 & - & 93.23 & 6.15 \\
\hline 4.67 & 93.72 & 4.20 & 95.73 & - & 96.04 & 5.35 \\
\hline 5.75 & 94.24 & 3.80 & 94.05 & 5.10 & 95.21 & 4.10 \\
\hline 7.69 & - & 1.95 & - & 5.00 & 95.36 & 4.15 \\
\hline 8.62 & 89.29 & 3.20 & 90.55 & 4.00 & 96.91 & 3.85 \\
\hline 9.93 & 93.66 & 1.95 & 88.89 & 5.40 & 89.89 & 5.00 \\
\hline \multirow[t]{2}{*}{11.40} & 90.28 & 3.80 & 88.86 & 5.60 & 90.52 & 4.55 \\
\hline & \multicolumn{2}{|c|}{ Group IV } & \multicolumn{2}{|c|}{ Group V } & \multicolumn{2}{|c|}{ Group VI } \\
\hline 0.00 & 100.00 & 0.00 & 100.00 & 0.00 & 100.00 & 0.00 \\
\hline 0.50 & 91.85 & 6.15 & 93.78 & 5.05 & 92.93 & 5.60 \\
\hline 1.40 & 93.41 & 5.60 & 94.52 & 5.90 & 93.58 & 4.65 \\
\hline 2.45 & 94.46 & 6.70 & 93.83 & 6.50 & 92.29 & 7.15 \\
\hline 3.35 & 92.34 & 5.50 & 94.09 & 4.90 & 91.36 & 6.75 \\
\hline 4.67 & 97.15 & 5.10 & 94.02 & 4.95 & 92.86 & 5.75 \\
\hline 5.75 & 94.73 & 4.25 & 95.02 & 4.25 & 94.10 & 4.75 \\
\hline 7.69 & - & 4.30 & - & 4.00 & 94.17 & 4.85 \\
\hline 8.62 & 91.71 & 3.65 & 90.82 & 3.90 & 92.33 & 4.10 \\
\hline 9.93 & 89.19 & 4.15 & 89.49 & 4.85 & 88.31 & 5.20 \\
\hline 11.40 & 89.90 & 4.80 & 90.41 & 5.15 & 90.82 & 5.30 \\
\hline
\end{tabular}


The method was nevertheless sufficiently accurate for describing the leaching process based on DOM concentration estimates.

The leaching rate was evaluated by fitting the experimental data to the kinetic model of monomolecular irreversible reactions (Levenspiel, 1986), which derives from the analytical integration of Equation 2. As already mentioned in the last section, the experimental conditions employed resulted in relatively low values of DOM mineralization rates, ideally suited for the application of Levenspiel's model.

$$
\mathrm{DOM}=\mathrm{POM}_{1} \times \frac{\mathrm{k}_{1}}{\mathrm{k}_{2}-\mathrm{k}_{1}} \times\left(\mathrm{e}^{-\mathrm{k}_{1} \mathrm{t}}-\mathrm{e}^{-\mathrm{k}_{2} \mathrm{t}}\right)
$$

where:

$\mathrm{POM}_{1}=$ total amount of leached matter from the detritus.

It was assumed that $\mathrm{k}_{2}$ (DOM mineralization rate) was the same for all bottles since they were stored under identical conditions and, therefore, all DOM fractions should have the same rates. Based on this assumption, the leaching rate, $\mathrm{k}_{1}$, was obtained from the fitting procedure.

The Fig. 1 shows the time dependence of DOM amounts (formation and consumption) and also includes the theoretical curves obtained from the kinetics model of Equation 4. The coefficients arising from the fitting procedure are listed in Table 3. It may be observed that for Scirpus cubensis the quantity of material available for leaching is relatively low (from 5 to 8 percent) when compared to the values presented by Bianchini Jr. (1982) for the species:
Nymphoides indica, Nymphaea ampla, Ludwigia sp., Poligonum sp., Pontederia cordata, Pontederia lanceolata, Mayaca sellowianna, Rinchospora gigantea, and Eleocharis mutata. In these species, the amount of leachate material varied from 16 to 47 percent. It must be considered, however, that in the present work all particulate material (detritus + microorganisms) was accounted for, whereas in the Bianchini study (1982) the litter bags method was employed in which only the fractions remaining following filtering (with a given mesh) are quantified. It can also be noted that the mechanical fragmentation process tended to increase somewhat the amount of material to be dissolved $\left(\mathrm{POM}_{1}\right)$. This process, however, caused a decrease in the leaching rate, especially for fragments smaller than $1.13 \mathrm{~mm}$ (groups IV, V, and VI). These two effects probably appeared because fractions of refracting matter became soluble. Even though changes could be measured in the dissolution rates and the quantities of material to be dissolved, these changes were small compared to the changes imposed in the initial stages of the experiments.

As can be seen in Fig. 2, for the smaller detritus particles (groups III, IV, V, and VI) degradation caused no significant changes in $\mathrm{pH}$. For the other groups (I and II) the $\mathrm{pH}$ approached neutrality as time elapsed. From these results it may be inferred that the $a$ priori fragmentation of detritus, which increased its specific area, favored oxidative processes (formation of humic compounds and $\mathrm{CO}_{2}$ ). This is due to the following factors: i) possible chemical reaction occurrences; ii) access of microorganisms and exoenzimes to unprotected structural elements, such as the matrix which consisted of lignin and cellulose.

TABLE 3

The changes of $\mathrm{POM}_{1}$, leaching rates $\left(\mathrm{k}_{1}\right)$ and half-time of the leaching process $\left(\mathrm{t}_{1 / 2}\right)$ as a function of $S$. cubensis particle size.

\begin{tabular}{|c|c|c|c|c|}
\hline Group & $\mathbf{P O M}_{\mathbf{1}}(\mathbf{m g})$ & $\mathbf{P O M}_{\mathbf{1}}(\boldsymbol{\%})$ & $\left.\mathbf{k}_{\mathbf{1}} \mathbf{( d a y}^{\mathbf{- 1}}\right)$ & $\mathbf{t}_{\mathbf{1} / \mathbf{2}}(\mathbf{d a y})$ \\
\hline I & 102.59 & 5.2 & 5.44 & 0.127 \\
\hline II & 176.76 & 8.8 & 7.23 & 0.096 \\
\hline III & 143.14 & 7.2 & 6.18 & 0.112 \\
\hline IV & 141.67 & 7.1 & 4.31 & 0.160 \\
\hline V & 138.14 & 6.9 & 2.69 & 0.257 \\
\hline VI & 163.62 & 8.2 & 2.42 & 0.286 \\
\hline
\end{tabular}



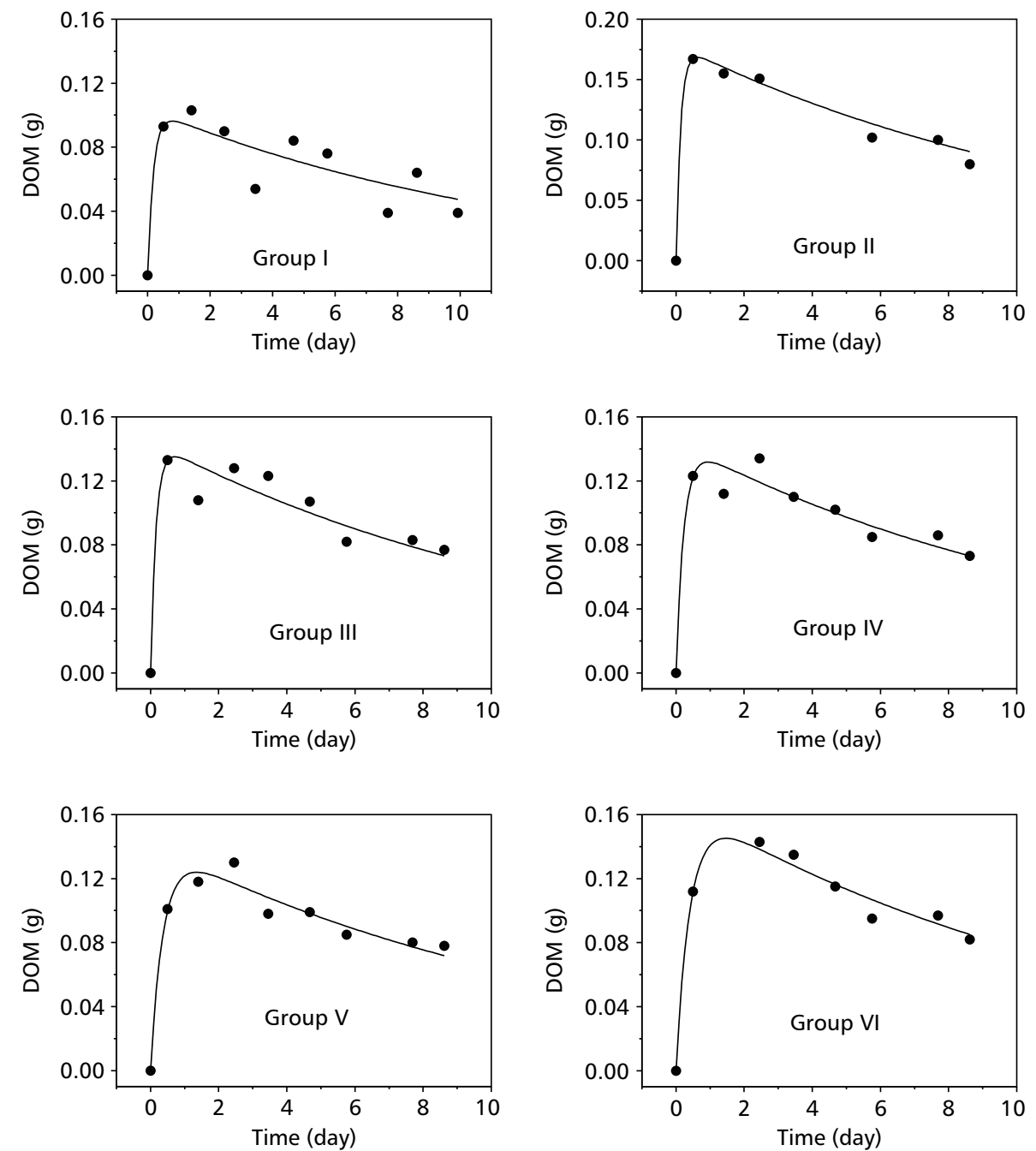

Fig. 1 - Changes of DOM during the decay of S. cubensis with different particle sizes.

Time dependence of the electrical conductivity is shown in Fig. 3. It may be seen that fragmentation slightly increased the electrolyte amount released, as occurred for DOM. However, electrolyte incorporation (microbial uptake) appears to have been inhibited in the flasks containing the smallest detritus, probably due to the formation of humic compounds that may have been chelated to the electrolytes, thus preventing them from being incorporated. The results shown in
Fig. 3 also suggest that the kinetics of the electrolyte material are similar to that of organic compounds. But electrolyte disappearance would be associated with the uptake and adsorption processes, while DOM decay would be associated with mineralization. It was not possible, however, to apply the kinetics model of Equation 4 to the electrolyte results because of the dispersion in the experimental results, probably caused by the high rates of re-cycling of these elements. 

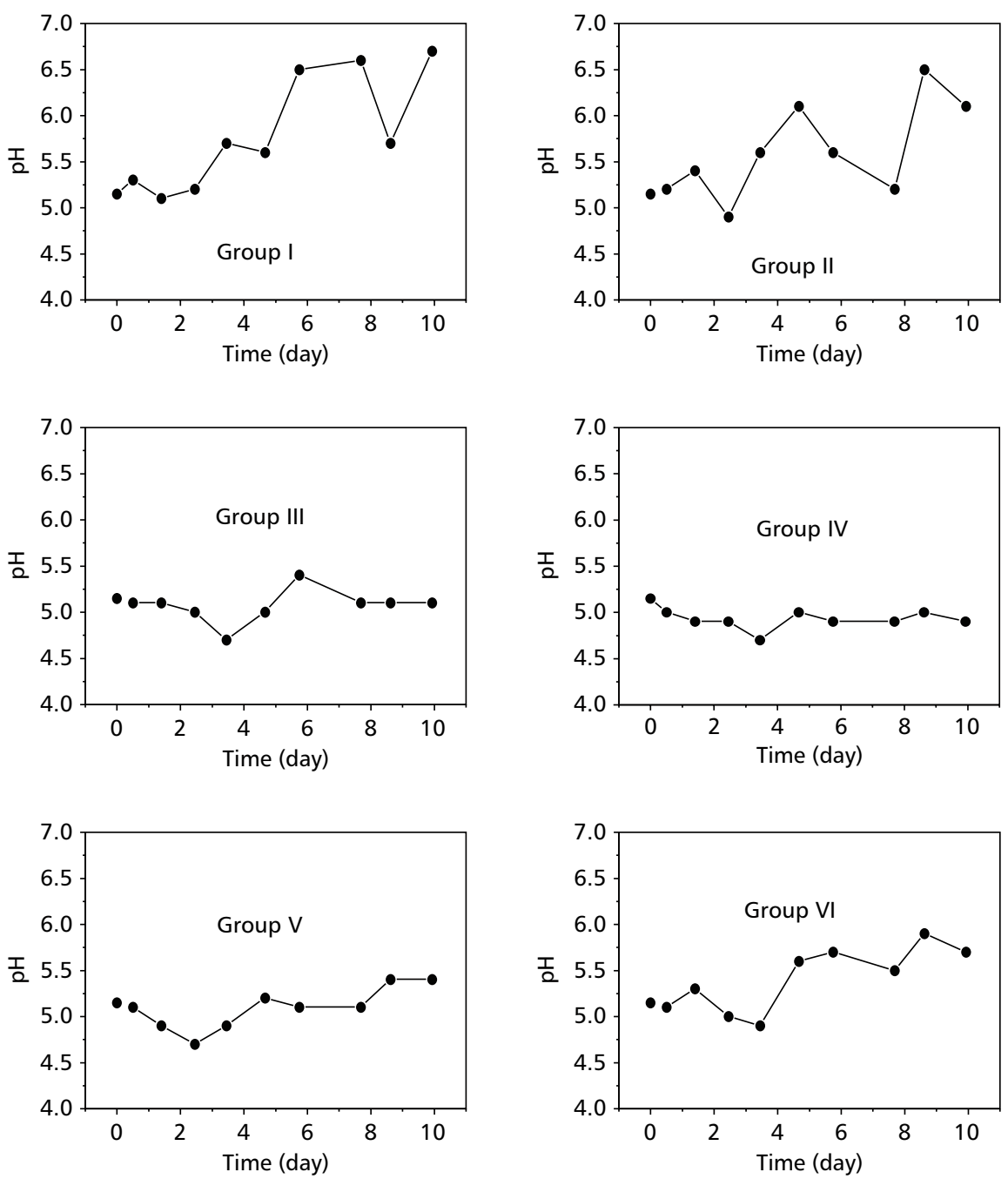

Fig. 2 - Changes of $\mathrm{pH}$ during the decay of $S$. cubensis with different particle sizes.

The results of the formation of colored compounds are shown in Fig. 4. In order to investigate the effects of the initial detritus size, optical density changes up to the 3 rd day of experiments were adjusted to the first order kinetics model of Equation 5 (Jфrgensen, 1986; Thormann \& Müeller, 1987). Restricting data use to that of the first 3 days was based on the assumption that after this period the formation of colored compounds should come mainly from DOM humification rather than from leaching.

$$
\mathrm{OD}_{\mathrm{t}}=\mathrm{OD}_{\mathrm{MAX}} \times\left(1-\mathrm{e}^{-\mathrm{kt}}\right)
$$

From the fitting procedure, it may be concluded that fragmentation increased both the quantity $\left(\mathrm{OD}_{\mathrm{MAX}}\right)$ and the rate of appearance of colored compounds (k). Basically, the leachate becomes colored due to two interdependent processes: pigment release and humic compound formation (Bianchini Jr., 1985). The latter compounds originate from chemical reactions in the leachate and from products re-synthesized by microorganisms. 

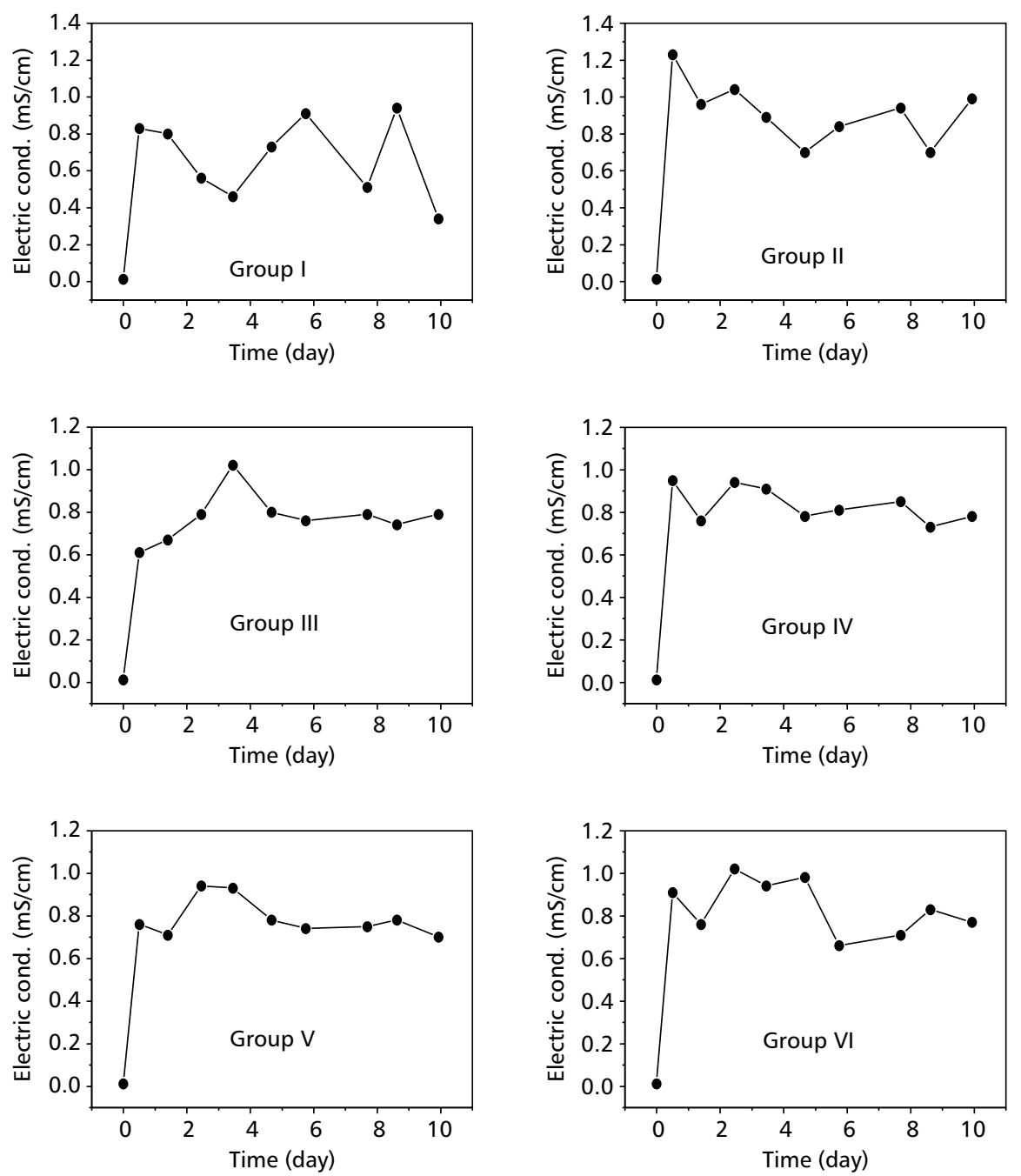

Fig. 3 - Changes of electrical conductivity during the decay of $S$. cubensis with different particle sizes.

When data obtained after the 3rd day of experiments are considered, it is seen that the smaller leached fragments have stronger color if compared to the fragments from group I $(10 \mathrm{~cm})$. One may also infer that the trend towards the leaching of compounds prone to humification was already present even for relatively large fragments (of the order of $1 \mathrm{~cm}$ ). Such compounds should include polyphenolics, carbohydrates, and aminebased compounds (Bianchini Jr. et al., 1984; Bianchini Jr. \& Toledo, 1988; Sieburth \& Jensen,
1968, 1969; Wetzel, 1983). Indeed, these results corroborate the above-mentioned assumptions that formation of humic compounds is favored by fragmentation.

The effects of particle size are summarized in Fig. 5. It must be noted that the $\mathrm{POM}_{1}$ yield increases with increasing $\mathrm{OD}_{\mathrm{MAX}}$ yield for, as shown in Fig. 5a. These results show that the mechanical fragmentation process increases the soluble detritus amount, which then enhances the rate and yield of formation of colored compounds. 

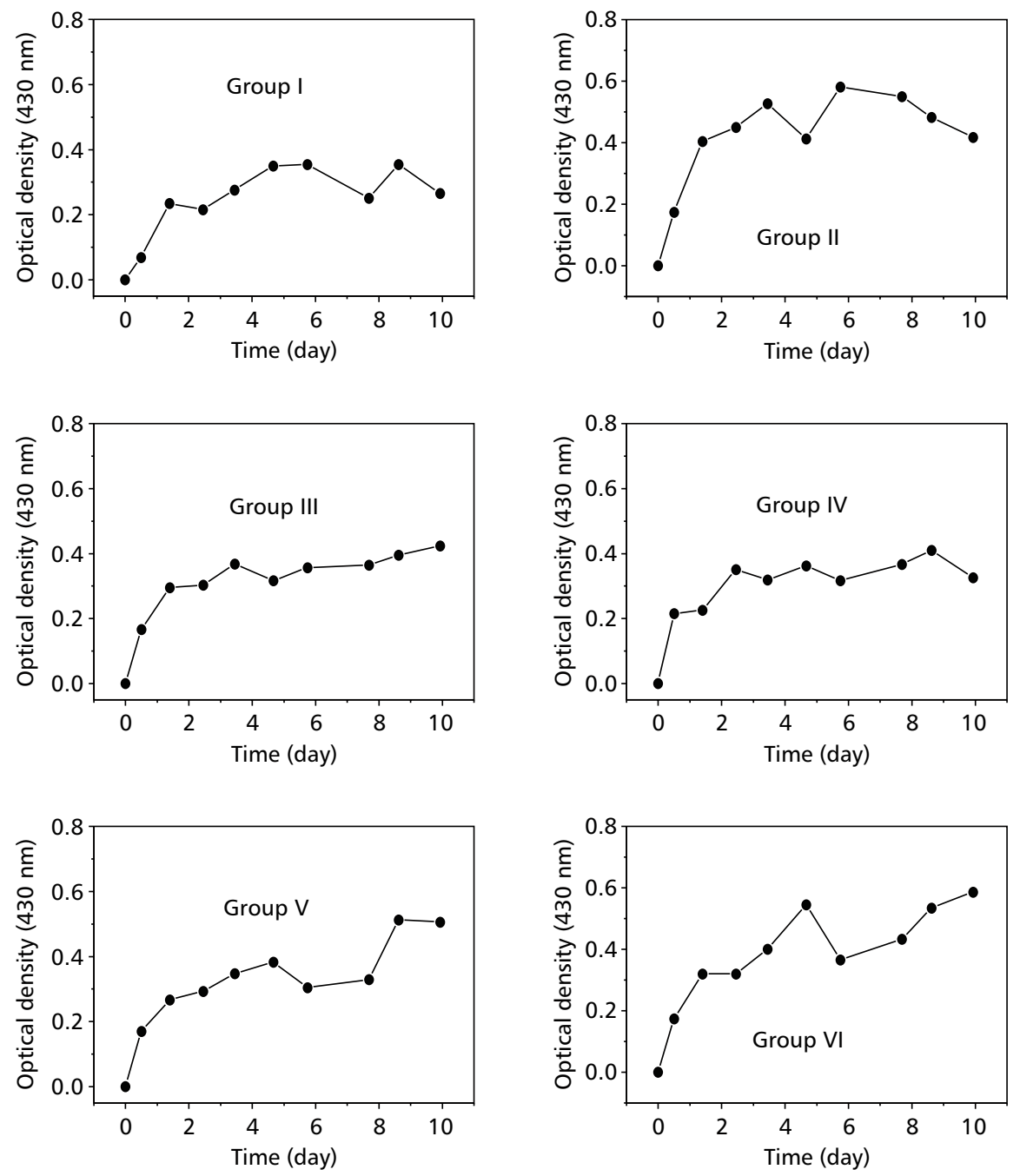

Fig. 4 - Changes in optical density during the decay of $S$. cubensis with different particle sizes.

On the other hand, these phenomena cause the leaching rates to decrease, probably because microorganisms have access to refracting matter (Fig. $5 b)$. With regard to the cycling of detritus in naturally occurring aquatic systems, it is likely that the fragmentation process is mostly associated with the amount, rather than with the leaching rates, of compounds (organic and inorganic) released into the water. This process is probably even more important in qualitative modifications of particulate detritus, by inducing the formation of humic compounds and other catabolic processes involved in biological oxidations.
In this context, the importance of benthic communities and other decomposers may be emphasized, for comminuition (mechanical fragmentation + digestion) can significantly enhance the degrading processes of organic resources, as in the case of the role played by insects in the terrestrial ecosystem. For the Lagoa do Infernão, in particular, ongoing studies show that the benthic community is practically nonexistent probably because of the low dissolved oxygen amounts in the sediment layer. Invertebrates typical of this community can be found, however, in the rizosphere of $S$. cubensis (Strixino et al., pers. com.). 

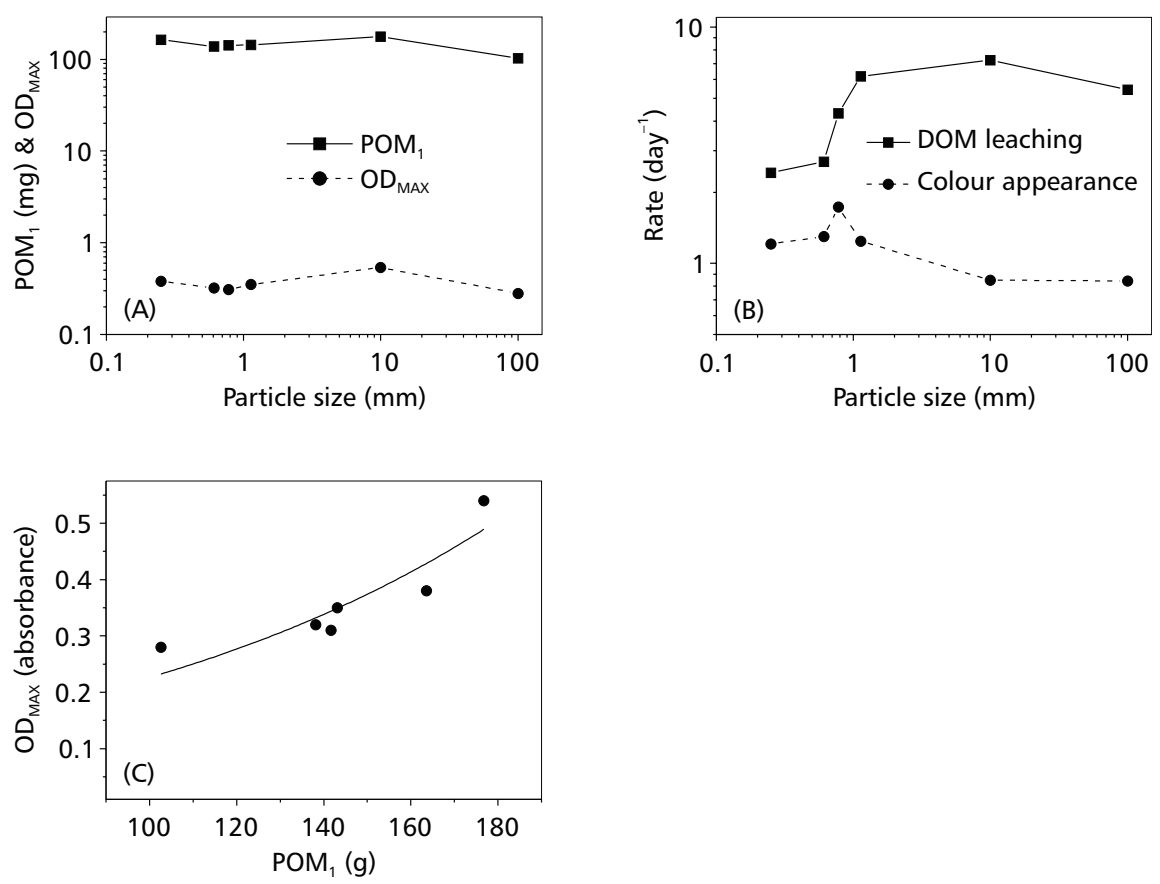

Fig. 5 - Effect of particle size of S. cubensis on: A) the total amounts of $\mathrm{POM}_{1}$ and $\mathrm{OD}_{\mathrm{MAx}}$; B) the rates of leaching and of appearance of colored compounds. Also shown is the relationship between total amount leached $\left(\mathrm{POM}_{1}\right)$ and the potential appearance of colored compounds $\left(\mathrm{OD}_{\mathrm{MAX}}\right)$.

\section{CONCLUSIONS}

Under the experimental conditions employed in the present work, one may conclude that for the Scirpus cubensis, the fragmentation process: 1) tended to increase the detritus fraction to be dissolved $\left(\mathrm{POM}_{1}\right)$ and to decrease the leaching rates $\left(\mathrm{k}_{1}\right)$, owing to the possible dissolution of refracting matter; 2) favored the rates of formation and increased the amount of colored compounds, probably by increasing the quantity of polyphenolics and other structural compounds (such as polysaccharides and amine-based compounds); 3) appeared to have favored the release of dissolved electrolytes; and 4) retained the acidity of the bottles.

Acknowledgments - The authors thank Fundação de Amparo à Pesquisa do Estado de São Paulo (FAPESP) for financing these essays (Process n. 91/1303-3) and Dr. Osvaldo N. Oliveira Jr. (IFSC-USP) for proofreading the manuscript.

\section{REFERENCES}

ALBUQUERQUE, A. L. S., 1992, Composição e dinâmica da matéria orgânica na Planície de Inundação do Rio MogiGuaçu, Estação Ecológica de Jataí, Luiz Antonio, SP. Dissertação de Mestrado, PPGERN, UFSCar, São Carlos.

BALLESTER, M. V. R., 1994, Emissões de metano na Planície de Inundação do Rio Mogi-Guaçu (Estação Ecológica de Jataí, São Paulo). Tese de Doutorado, PPGERN, UFSCar, São Carlos.

BIANCHINI Jr., I., 1982, Contribuição ao estudo da decomposição de plantas aquáticas. Dissertação de Mestrado, Depto. Ciências Biológicas, UFSCar, São Carlos.

BIANCHINI Jr., I., 1985, Estudo da humificação de Nymphoides indica (L.) O. Kuntze. Tese de Doutorado, Depto. Ciências Biológicas, UFSCar, São Carlos.

BIANCHINI Jr., I., TOLEDO, A. P. P. \& TOLEDO, S. H. P. P., 1984, Influência do tempo na variedade e quantidade de polifenóis dissolvidos, originados da decomposição de plantas aquáticas. Anais, $4^{\text {th }}$ Seminário Regional de Ecologia, DCB-UFSCar, São Carlos, pp. 167-181. 
BIANCHINI Jr., I. \& TOLEDO, A. P. P., 1988, Decomposição de macrófitas aquáticas - estudo da variação do $\mathrm{pH}$ e densidade óptica em ensaios sob diferentes condições de atmosfera e luminosidade. Anais, 5 Seminário Regional de Ecologia, São Carlos, pp. 167-181.

BREZONIK, P. L., 1994, Chemical kinetics and process dynamics in aquatic systems. Lewis, Boca Raton, 754p.

HOWARD-WILLIAMS, C., ESTEVES, F. A., SANTOS, J. E. dos \& DOWNES, M. T., 1989, Short term nitrogen dynamics in a small Brazilian wetland (Lago Infernão, São Paulo). J. of Trop. Ecol., 5: 323-335.

JфRGENSEN, S. E., 1986, Fundamentals of ecological modelling. Developments in environmental modelling, 9. Elsevier, Amsterdam, 389p.

JUNK, W. J., 1980, Áreas inundáveis, um desafio para limnologia. Acta Amazo., 10: 775-795.

LEVENSPIEL, O., 1986, Engenharia das reações químicas: cinética química aplicada. vol. 1. Edgard Blucher, São Paulo, 211p.

LUSH, D. L. \& HYNES, H. B. N., 1973, The formation of particles in freshwater lecheates of dead leaves. Limnol. Oceanog., 18: 968-977.

MINDERMANN, G., 1968, Addition, decomposition and accumulation of organic matter in forests. J. Ecol., 56: 355 562.

NOGUEIRA, F. M. B., 1989, Importância das macrófitas aquáticas Eichhornia azurea Kunth e Scirpus cubensis Poepp \& Kunth na ciclagem de nutrientes e nas principais características limnológicas da Lagoa Infernão (SP). Dissertação de Mestrado, PPG Ecologia e Recursos Naturais, UFSCar, São Carlos.
SANTOS, J. E. dos \& MOZETO, A. A., 1992, Programa de análise de ecossistemas e monitoramento ambiental: Estação Ecológica de Jataí (Luiz Antonio, SP). Ecologia de áreas alagáveis da planície de inundação do rio Mogi-GuaçuProjeto Jataí. Relatório Técnico. PPG. Ecologia e Recursos Naturais, UFSCar, São Carlos.

SIEBURTH, J. M. C. N. \& JENSEN, A., 1968, Studies on algal substances in the sea. I Gelbstoff (humic material) in terrestrial and marine waters. J. Exp. Mar. Biol. Ecol., 2: 174-189.

SIEBURTH, J. M. C. N. \& JENSEN, A., 1969, Studies on algal substances in the sea. II the formation of gelbstoff (humic material) by exudates of phaephyta. J. Exp. Mar. Biol. Ecol., 3: 275-289.

STEVENSON, F. J., 1982, Humus chemistry. Wiley, New York, $443 \mathrm{p}$.

SWIFT, M. J., HEAL, D. W. \& ANDERSON, J. M., 1979, Studies in ecology-decomposition in terrestrial ecosystems. Blackwell, Oxford, 371p.

THORMANN, R. V. \& MÜELLER, J. A., 1987, Principles of surface water quality modeling and control. Harper \& Row, New York, 643p.

THURMAN, E. M., 1985, Organic geochemistry of natural waters. Nijhoff/Junk Po., Netherlands, 497p.

TOLEDO, A. P. P., 1973, Contribuição ao estudo físico-químico de ácido húmico extraído de sedimento. Dissertação de Mestrado, Depto. de Química, USP, São Paulo.

WETZEL, R. G., 1983, Limnology. Saunders, Philadelphia, 767p. 